\title{
How do financial leverage and supply chain finance influence firm performance? Evidence from construction sector
}

\author{
Toan Ngoc Bui ${ }^{a^{*}}$
}

${ }^{a}$ Faculty of Finance and Banking, Industrial University of Ho Chi Minh City (IUH), Vietnam

\begin{tabular}{l}
\hline C H R O N I C L E \\
\hline Article history: \\
Received October 20, 2019 \\
Received in revised format \\
November 25, 2019 \\
Accepted December 242019 \\
Available online \\
December 242019 \\
\hline Keywords: \\
Cash conversion cycle \\
Construction sector \\
Financial leverage \\
Performance \\
Vietnam
\end{tabular}

\begin{abstract}
A B S T R A C T
This paper investigates the impact of financial leverage and supply chain finance on firm performance of Vietnamese construction sector. Although there is a big gap in the literature needed to be filled, little empirical evidence can be found on this interesting topic. Therefore, the results are essential for Vietnamese firms, particularly those in construction industry. By adopting the generalized method of moment (GMM), the results reveal the significant influence of financial leverage and supply chain finance on the performance of construction firms. In particular, firm performance (FP) is more influenced by financial leverage (FL) than supply chain finance (SCF). The findings also show that supply chain finance plays a key role in enhancing firm performance. Meanwhile, more debts and their inefficient use exert a negative impact on firm performance, which is an unprecedented finding of this study.
\end{abstract}

(C) 2020 by the authors; license Growing Science, Canada.

\section{Introduction}

In the context of the international integration, Vietnamese construction sector is facing a number of big challenges. Particularly, capital access is one of the matters which attracts much attention from construction firms. Especially, Vietnam economy has just overcome a recession caused by the global financial crisis, so it becomes more difficult for construction companies in accessing to capital. This source helps these firms not only maintain their operations but also raise their competitive ability against other multinational firms with high financial capacity expanding to Vietnam's market. Together with using financial leverage through traditional channels, specifically credit organizations, construction firms show more concern on short-term credit through supply chain finance. It is because short-term credit allows enterprises optimise their working capital at a low cost (Wuttke et al., 2013), thereby enhancing firm performance (Lekkakos \& Serrano, 2016). Although the role of financial leverage and supply chain finance in improving firm performance cannot be denied, their concurrent impact on corporate performance has not been empirically examined in many studies. Hence, this paper aims to give first empirical evidence on this influence. Especially, the data are obtained from Vietnamese companies in construction industry which is growing impressively but still facing many difficulties in the capital access. Therefore, this paper is expected to reveal more interesting findings.

* Corresponding author

E-mail address: buingoctoan@iuh.edu.vn (T. N. Bui)

(C) 2020 by the authors; licensee Growing Science. doi: $10.5267 /$ j.uscm.2019.12.003 


\section{Literature review}

\subsection{Financial leverage and firm performance}

Financial leverage refers to how firms use their debt. In their use, firms experience benefits of tax shields which lower the overall amount of income tax which they need to pay for the state by a reduction in taxable income, thereby enhancing their performance. In other words, the use of financial leverage possibly exerts positive influence on the corporate performance. This is consistent with what have been reported by Burja (2011), Seelanatha (2011), Nirajini and Priya (2013), Sivathaasan et al. (2013), Ghayas and Akhter (2018). However, the use of financial leverage can also bring firms more financial risks. Indeed, more debts and their inefficient use put firms in bankruptcy risk, which may negatively affect the corporate performance. The negative influence of financial leverage on firm performance has been also found by Azhagaiah and Gavoury (2011), Malik (2011), Akinlo and Asaolu (2012), González (2013), Hamid et al. (2015), Vithessonthi and Tongurai (2015), Daud et al. (2016), Ameen and Shahzadi (2017).

\subsection{Supply chain finance and firm performance}

Supply chain finance is frequently measured through cash conversion cycle (Zhang et al., 2019). Accordingly, cash conversion cycle is defined as the period starting from the cash outlay to cash recovery (Bui, 2020). Reducing cash conversion cycle makes the financial link among participants stronger (Wuttke et al., 2013), which means supply chain finance performs better. More than that, this allows its participants take use of short-term credit at a low cost, thereby boosting firm performance (Bui, 2020). Therefore, supply chain finance greatly contributes in optimizing corporate financial flows (Pfohl \& Gomm, 2009), stabilising the holistic supply chain (Klapper, 2006), and most notably, enhancing firm performance (Lekkakos \& Serrano, 2016). In other words, supply chain finance is positively correlated with firm performance meanwhile cash conversion cycle has a negative impact on how firms perform. This negative influence has been revealed in studies of Zhang et al. (2019) and Bui (2020).

\section{Data and Methodology}

\subsection{Data Collection}

Data are collected from financial reports of 30 construction companies listed on Vietnam stock market. The data are obtained in the period from 2015 to 2018. Further, data on economic growth are collected from World Bank source.

\subsection{Methodology}

The study analyses the impact of financial leverage and supply chain finance on performance of construction firms in Vietnam. Therefore, the model is estimated by adopting the Pooled Regression model (Pooled OLS), Fixed effects model (FEM) and Random effects model (REM). Next, the Generalized Method of Moment (GMM) which allows to control potential endogeneity and detect violations of null hypotheses is employed in the estimation to assure the reliability of the results (Doytch \& Uctum, 2011). Following earlier researchers, the author measures firm performance (FP) by return on assets ratio (ROA). Financial leverage (FL) is measured by total debt to total equity while supply chain finance (SCF) is performed by cash conversion cycle (CCC). In addition, firm size (logarithm of total assets) and economic growth are included as control variables in the model. The former representing for firm characteristics has been adopted in the analyses of Malik (2011), Akinlo and Asaolu (2012), Sivathaasan et al. (2013), Hamid et al. (2015), Vithessonthi and Tongurai (2015), Daud et al. (2016) while the latter as an indicator of the macroeconomy was also been found in the research of Vithessonthi and Tongurai (2015). Therefore, the research model is estimated in the following equation: 


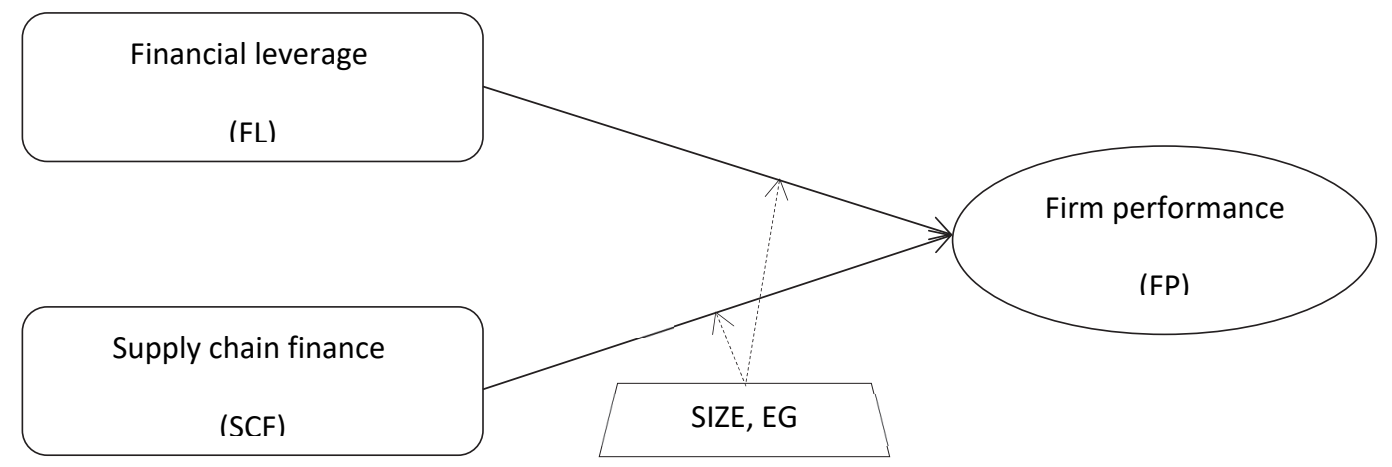

Source: Research model proposed by the author.

Fig. 1. The impact of financial leverage and supply chain finance on firm performance

where:

Dependent variable: Firm performance (FP).

Independent variables: Financial leverage (FL), supply chain finance (SCF).

Control variables: Firm size (SIZE), economic growth (EG).

The term $\varepsilon$ is the model regression error term.

Table 1

Summary of variables

\begin{tabular}{lcl}
\hline \multicolumn{1}{c}{ Variable name } & Code & Measurement \\
\hline Firm performance & FP & $\begin{array}{l}\text { Dependent variable } \\
\text { Net income / Total assets } \\
\text { Independent variables } \\
\text { Total debt / Total equity }\end{array}$ \\
$\begin{array}{l}\text { Financial leverage } \\
\text { Supply chain finance }\end{array}$ & FL & $\begin{array}{l}\text { Logarithm of cash conversion cycle } \\
\text { Cash conversion cycle }(\mathrm{CCC})=\text { Days receivable }+ \text { Days inventories }- \text { Days } \\
\text { payable }=(\text { trade receivable / sales }) * 365+(\text { total inventories } / \text { cost of goods } \\
\text { sold }) * 365 \text { - (trades payable / cost of goods sold }) * 365 \\
\text { Control variables }\end{array}$ \\
Firm size & SIZE & $\begin{array}{l}\text { Logarithm of total assets } \\
\text { Annual growth of gross domestic product }\end{array}$ \\
\hline Economic growth & EG &
\end{tabular}

\section{Empirical Results}

The correlation among variables are shown in Table 2 as follows,

Table 2

Variable correlations

\begin{tabular}{cccccc}
\hline & FP & FL & SCF & SIZE & EG \\
\hline FP & 1.0000 & & & & \\
FL & -0.2265 & 1.0000 & & & \\
SCF & -0.2265 & -0.0761 & 1.0000 & 1.0000 & 1.0000 \\
SIZE & 0.1754 & 0.0571 & -0.1794 & 0.1225 & -0.1709 \\
EG & 0.3858 & 0.0155 & &
\end{tabular}

Source: Author's computed.

Table 2 shows that the independent variables, particularly financial leverage (FL) and supply chain finance (SCF) are negatively associated with firm performance (FP). Meanwhile, control variables, specifically firm size (SIZE) and economic growth (EG) are positively correlated to firm performance (FP). Next, the Pooled Regression model (Pooled OLS), Fixed effects model (FEM) and Random effects model (REM) are adopted to estimate the model. 
Table 3

Regression results

\begin{tabular}{lccc}
\hline \multicolumn{1}{c}{ FP } & Pooled OLS & FEM & REM \\
\hline Constant & $-29.2821^{* * *}$ & $-58.4203^{* * *}$ & $-34.7289^{* * *}$ \\
FL & $-0.0613^{* * *}$ & -0.0449 & $-0.0577^{* *}$ \\
SCF & $-0.0003^{* *}$ & -0.0001 & -0.0003 \\
SIZE & 0.5164 & 1.5909 & 0.7102 \\
EG & $3.8750^{* * *}$ & 3.8004 & $3.8812^{* * *}$ \\
R $^{2}$ & $22.94 \%$ & $29.03 \%$ & $28.21 \%$ \\
Significance level & $\mathrm{F}(4,145)=10.79$ & $\mathrm{~F}(4,116)=11.86$ & Wald chi2 $2(4)=50.46$ \\
F test & Prob $>\mathrm{F}=0.0000^{* * *}$ & $\mathrm{Prob}>\mathrm{F}=0.0000^{* * *}$ & Prob $>$ chi2 $=0.0000^{* * *}$ \\
& & $\mathrm{~F}(29,116)=2.84$ & \\
Hausman test & & Prob $>\mathrm{F}=0.0000^{* * *}$ & \\
\end{tabular}

Note: ${ }^{*},{ }^{* *}$ and ${ }^{* * *}$ indicate significance at the $10 \%, 5 \%$ and $1 \%$ level, respectively.

Source: Author's computed.

It can be seen from Table 3 that F-test is significant at the $1 \%$ level (Prob $>F=0.0000)$. Meanwhile, Hausman test shows no statistical significance (Prob $>$ chi $2=0.7459)$. It can thus be concluded that the Random effects model (REM) is superior to the other, so it is chosen for testing the model.

Table 4

Results of testing multicollinearity

\begin{tabular}{lccccc}
\hline Variable & FL & SCF & SIZE & EG & Mean VIF \\
\hline VIF & 1.01 & 1.06 & 1.04 & 1.04 & 1.04 \\
\hline
\end{tabular}

Source: Author's computed.

Table 4 reveals that there are no serious issues of multicollinearity (Mean VIF $<10$ ).

Table 5

Results of testing heteroscedasticity and autocorrelation

$\begin{array}{cc}\text { Heteroscedasticity test } & \text { Autocorrelation test } \\ \text { chibar } 2(01)=19.60 & \mathrm{~F}(1,29)=4.530 \\ \text { Prob }>\text { chi } 2=0.0000^{* * *} & \text { Prob }>\mathrm{F}=0.0419^{* *}\end{array}$

Note: ${ }^{* *}$ and ${ }^{* * *}$ indicate significance at the $5 \%$ and $1 \%$ level, respectively.

Source: Author's computed.

Table 5 shows that heteroscedasticity and autocorrelation really exist at the $1 \%$ (Prob $>$ chi $2=0.0000$ ) and 5\% (Prob $>F=0.0419)$ level of significance, respectively. Thus, the author chooses the generalized method of moment (GMM) for the analysis in order to avoid heteroscedasticity and autocorrelation issues. Also, GMM can address potential endogeneity.

Table 6

GMM estimation results

\begin{tabular}{|c|c|c|}
\hline FP & Coef. & $\mathbf{P}>|\mathbf{z}|$ \\
\hline Constant & -9.3697 & 0.174 \\
\hline FL & -0.0791 & $0.000^{* * *}$ \\
\hline SCF & -0.0002 & $0.045^{* *}$ \\
\hline SIZE & 0.3309 & 0.160 \\
\hline EG & 1.2432 & $0.041^{* *}$ \\
\hline Significance level & \multicolumn{2}{|c|}{ Wald chi2 $(3)=33.89$ Prob $>$ chi $2=0.000^{* * *}$} \\
\hline Arellano-Bond test for $\mathrm{AR}(2)$ in first differences & \multicolumn{2}{|c|}{$z=0.34 \operatorname{Pr}>z=0.732$} \\
\hline Sargan test & \multicolumn{2}{|c|}{ Chi-Square $(5)=4.30 \quad$ Prob $>$ chi $2=0.506$} \\
\hline
\end{tabular}

Note: ${ }^{* *}$ and ${ }^{* * *}$ indicate significance at the $5 \%$ and $1 \%$ level, respectively.

Source: Author's computed.

Table 6 shows that results of GMM estimator is appropriate and valid at the $1 \%$ level of significance (Prob $>$ chi $2=0.000)$. Also, Sargan test shows that instruments adopted are suitable. Accordingly, 
financial leverage (FL) exerts a negative (-0.0791) impact on firm performance (FP) at the $1 \%$ level of significance while supply chain finance (SCF) negatively (-0.0002) affects firm performance (FP) at the $5 \%$ significance level. Therefore, firm performance (FP) is more influenced by financial leverage (FL) than supply chain finance (SCF). Furthermore, the result reveals the positive causality between economic growth (EG) and firm performance (FP) at the $5 \%$ level of significance.

Hence, the results of the model take the following equation:

$$
\mathrm{FP}_{i t}=-0.0791 \mathrm{FL}_{i t}-0.0002 \mathrm{SCF}_{i t}+1.2432 \mathrm{EG}_{\mathrm{t}}+\varepsilon_{i t}
$$

The impact of financial leverage on firm performance: The findings show that the influence of financial leverage (FL) on firm performance (FP) is negative (-0.0791) and significant at the $1 \%$ level. Accordingly, the inefficient use of debt causes a considerable decrease in firm performance. This is suitable for the reality in Vietnam. Recently, Vietnam real estate industry has experienced many difficulties due to the negative impact of the international and national economy, causing lots of obstacles to construction sector, particularly making the capital use of construction firms inefficient. Also, these firms have to face more financial risks, which significantly affects their performance. This is in line with the findings of Azhagaiah and Gavoury (2011), Malik (2011), Akinlo and Asaolu (2012), González (2013), Hamid et al. (2015), Vithessonthi and Tongurai (2015), Daud et al. (2016), Ameen and Shahzadi (2017). Nevertheless, this is the first empirical evidence on the correlation between financial leverage and firm performance in construction sector, which is an interesting novelty of this study.

The impact of supply chain finance on firm performance: Supply chain finance (SCF) is negatively (- 0.0002) correlated to firm performance at the 5\% significance level. This finding corroborates what has been found by Zhang et al. (2019) and Bui (2020). Specifically, when cash conversion cycle is shortened (supply chain finance performs well), working capital and funds of its participants will increase. They are considerable capital sources with low cost supplying for the following operation cycle, so firm performance will be improved. In fact, Vietnam is a developing country whose ability and link among construction companies in the supply chain are limited. That is why the study along with its findings on the statistically significant causality between supply chain finance and firm performance is essential for Vietnam as well as other developing countries.

\section{Conclusions}

The results show that financial leverage and supply chain finance significantly influence how Vietnamese construction firms perform. Particularly, firm performance (FP) is far more influenced by financial leverage (FL) than supply chain finance (SCF). More than that, supply chain finance plays a major role in enhancing firm performance. However, more debts and their ineffective use are negatively linked to firm performance. The findings are first empirical evidence on the influence of financial leverage and supply chain finance on firm performance in construction sector. Therefore, they are essential for the management in construction industry to better supply chain finance and utilise financial

leverage efficiently for the performance improvement. In specific: (1) It is vital for the firms to make plans to use debt efficiently, combined with the prediction of customers' demands in order to set suitable loan plans; (2) It is necessary for the firms to participate in and improve supply chain finance to make use of its benefits. The paper succeeds in giving first empirical evidence on the influence of financial leverage and supply chain finance on the performance of Vietnamese construction firms. However, as a limitation of this study, the authors does not consider some control variables which may influence firm performance such as inflation, liquidity and firm management ability. This may be an interesting proposal for future research.

\section{References}

Akinlo, O., \& Asaolu, T. (2012). Profitability and Leverage: Evidence from Nigerian firms. Global Journal of Business Research, 6(1), 17-25. 
Ameen, A., \& Shahzadi, K. (2017). Impact of Capital Structure on Firms Profitability: Evidence from Cement Sector of Pakistan. Research Journal of Finance and Accounting, 8(7), 29-34.

Azhagaiah, R., \& Gavoury, C. (2011). The Impact of Capital Structureon Profitability with Special Reference to it Industry in India. Managing Global Transitions, 9(4), 371-392.

Bui, T.N. (2020). Supply chain finance, financial development and profitability of real estate firms in Vietnam. Uncertain Supply Chain Management, 8(1), 37-42.

Daud, W.M.N.W., Norwani, N.M., Mansor, A.A., \& Endut, W.A. (2016). Does Financing Decision Influence Corporate Performance in Malaysia?. International Journal of Economics and Financial Issues, 6(3), 1165-1171.

Doytch, N., \& Uctum, M. (2011). Does the worldwide shift of FDI from manufacturing to services accelerate economic growth? A GMM estimation study. Journal of International Money and Finance, 30(3), 410-427.

Burja, C. (2011). Factors influencing the companies' profitability. Annales Universitatis Apulensis Series Oeconomica, 13(2), 215-224.

Ghayas, A., \& Akhter, J. (2018). Impact of Capital Structure on Profitability: An empirical analysis of listed firms in India. Asian Journal of Managerial Science, 7(2), 1-6.

González, V.M. (2013). Leverage and corporate performance: International evidence. International Review of Economics and Finance, 25, 169-184.

Hamid, M.A., Abdullah, A., \& Kamaruzzaman, N.A. (2015). Capital Structure and Profitability in Family and Non-Family Firms: Malaysian evidence. Procedia Economics and Finance, 31, 44-55.

Klapper, L.F. (2006). The role of factoring for financing small and medium enterprises. Journal of Banking \& Finance, 30(11), 3111-3130.

Lekkakos, S.D., \& Serrano, A. (2016). Supply chain finance for small and medium sized enterprises: the case of reverse factoring. International Journal of Physical Distribution \& Logistics Management, 46(4), 367-392.

Malik, H. (2011). Determinants of Insurance Companies Profitability: an Analysis of Insurance Sector of Pakistan. Academic Research International, 1(3), 315-321.

Nirajini, A., \& Priya, K.B. (2013). Impact of Capital Structure on Financial Performance of the Listed Trading Companies in Sri Lanka. International Journal of Scientific and Research Publications, $3(5), 1-9$.

Pfohl, H.C., \& Gomm, M. (2009). Supply chain finance: optimizing financial flows in supply chains. Logistics Research, 1(3), 149-161.

Seelanatha, L. (2011). Determinants of firms' performance: some Chinese evidence. Investment Management and Financial Innovations, 8(3), 28-38.

Sivathaasan, N., Tharanika, R., Sinthuja, M., \& Hanitha, V. (2013). Factors determining Profitability: A Study of Selected Manufacturing Companies listed on Colombo Stock Exchange in Sri Lanka. European Journal of Business and Management, 5(27), 99-107.

Vithessonthi, C., \& Tongurai, J. (2015). The effect of leverage on performance: Domestically-oriented versus internationally-oriented firms. Research in International Business and Finance, 34, 265-280.

Wuttke, D.A., Blome, C., Foerstl, K., \& Henke, M. (2013). Managing the innovation adoption of supply chain finance - empirical evidence from six European case studies. Journal of Business Logistics, 34(2), 148-166.

Zhang, T., Zhang, C.Y., \& Pei, Q. (2019). Misconception of Providing Supply Chain Finance: Its Stabilising Role. International Journal of Production Economics, 213, 175-184.

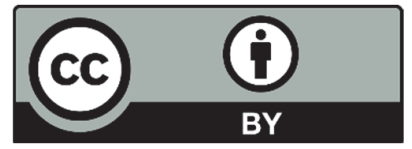

(C) 2020 by the authors; licensee Growing Science, Canada. This is an open access article distributed under the terms and conditions of the Creative Commons Attribution (CC-BY) license (http://creativecommons.org/licenses/by/4.0/). 